Jordan Klimek

Uniwersytet Szczeciński

\title{
W STRONĘ KULTURY MATERIALNEJ. ZARZĄDZANIE RYZYKIEM W DOBIE PÓŹNEJ NOWOCZESNOŚCI
}

\author{
Towards the material culture. The risk management in the era of postmodernity
}

\begin{abstract}
Streszczenie
W artykule podjęto próbę odpowiedzi na pytanie o aktualną kondycję społeczeństwa polskiego w kontekście rozważań nad wzrostem kultury materialnej, jaki dostrzegł Georg Simmel. Pod rozwagę wzięto koncepcję regresu kultury indywidualnej. Poszukując wyznaczników współczesnego stylu życia, oparto się na analizie danych zastanych, a także dotychczasowych ustaleń naukowo-badawczych. Zwrócono uwagę na liczne przeobrażenia w strukturze społecznej, a w szczególności na zmianę charakteru interakcji społecznych i osłabienie więzi w społeczeństwach. Ponadto wskazano na zjawisko zindywidualizowania społeczeństwa jako przejawu dążenia do realizacji własnych aspiracji.
\end{abstract}

Słowa kluczowe: konsumpcjonizm, kultura materialna, późna nowoczesność, socjologia codzienności, styl życia, wartości życiowe, ryzyko, zarządzanie ryzykiem

\begin{abstract}
This article is an attempt to answer the question about the current condition of Polish society in the context of reflections on the growth of material culture. The author considers the concept of regress of individual culture. The focus was on verifying of the validity of the theorem on the phenomenon of targeting material values. Attention has been paid to numerous transformations in the social structure, and in particular to the change in the nature of social interactions, weakening of social ties, etc. and the phenomenon of individualization of the society as a direction of accomplishing their own aspirations, ambitions.
\end{abstract}

Keywords: consumerism, materialistic culture, late modernity, sociology of everyday life, lifestyle, life values, risk, risk management

\section{Wprowadzenie}

Późnonowoczesna rzeczywistość społeczno-gospodarcza i takie zjawiska, jak globalizacja, konsumpcjonizmu oraz obecność w życiu codziennym zagrożenia i konieczności szacowania ryzyka skłaniają do refleksji nad zorientowaniem na wartości o charakterze materialistycznym. W obliczu niemożliwego do wyeliminowania poczucia zagrożenia wszelkie sposob y minimalizowania ryzyka (Giddens 2007), w tym także te związane z zabezpieczeniem finansowym, wydają się racjonalnym rozwiązaniem. Kapitał ekonomiczny można bowiem wymienić na inny kapitał, np. społeczny (Bourdieu 2005), i w ten sposób rozwiązać istotny problem.

Artykuł poświęcony jest rozważaniom nad aktualnością tezy Georga Simmla na temat wzrostu kultury materialnej. W związku z tym zastanawia aktualna kondycja społeczeństwa wobec zindywidualizowanego świata społecznego (Bauman 2008) i instrumentalnego charakteru relacji interpersonalnych. Interesujący poznawczo jest sposób radzenia sobie z potencjalnymi zagrożeniami w sytuacji wzrostu poziomu jakości 
życia (Włodarczyk 2015), a w szczególności postawy związane z gromadzeniem kapitału ekonomicznego jako środkiem zarządzana ryzykiem i niepewnością wobec wyzwań późnej nowoczesności.

\section{Georg Simmel i postulat wzrostu kultury materialnej}

Simmel, niemiecki filozof i teoretyk kultury żyjący w latach 1858-1918, zaobserwował przemiany w obrębie podziału pracy i własności materialnej wskazujące na regres kultury indywidualnej i zwrot orientacji życiowej w kierunku dóbr materialnych. Zmiana relacji interpersonalnych, która jest efektem gospodarki rynkowej, charakteryzuje się postawą określaną przez Simmla jako skierowana do osób nieznanych producentowi nawet z widzenia. Wskutek tego zainteresowanie obydwu stron cechuje bezlitosna rzeczowość, oparta na wyrachowanym, ekonomicznym egoizmie (Simmel 1969: 49). Prowadzi to do swoistej izolacji społecznej, spłycenia stosunków społecznych, ograniczenia ich do niemal wyłącznie instrumentalnego charakteru, a więc realizacji partykularnych interesów, o czym wspominali również m.in. Anthony Giddens (2007) czy Zygmunt Bauman (2006). Utrudnione jest funkcjonowanie w grupie, co skazuje człowieka na samotność i bycie niewolnikiem kultury obiektywnej (Simmel 2007: 29-30). Cechą charakterystyczną dla przemiany relacji interpersonalnych w wyniku rynkowego funkcjonowania w rzeczywistości społeczno-gospodarczej jest zatem anonimowość, która powoduje, że wszelkie kontakty społeczne odbywają się bardzo szybko, niemal błyskawicznie, aby nie tracić bezcennego czasu na zbędne zabiegi związane z zainteresowaniem interlokutorem czy też nawiązaniem z nim jakiejkolwiek głębszej więzi.

Gospodarka pieniężna prowadzi w efekcie do cynizmu relacji społecznych, polegającego na postawie sprowadzającej wszelkie aspekty życia społecznego do towarów na sprzedaż. Innymi słowy, chodzi tu o redukowanie poszczególnych celów do cynicznej postawy, w myśl której wszystko ma swoją cenę, a zatem wszystko można kupić lub sprzedać, w zależności od stosownej kwoty (Simmel 1997: 228). Jest to swoiste utowarowienie stosunków społecznych, sprowadzające ludzi do zwykłych trybów w bezosobowej machinie organizacyjnej. Tym samym można tutaj mówić o bezosobowości stosunków interpersonalnych. Wraz ze wzrostem znaczenia transakcji pieniężnych w życiu społecznym oraz ich urzeczowionych struktur zanika znaczenie jednostki, nazwane przez Simmla (1997: 167-168) upadkiem indywidualnej kultury subiektywnej. W praktyce życia społeczno-gospodarczego oznacza to, że pozycje społeczne przysłaniają konkretne osobowości, zatem przestaje mieć znaczenie, kto te pozycje zajmuje. Coraz mniej istotna jest osoba pełniąca daną funkcję, ponieważ łatwo można ją zastąpić kimś innym (Sikorski 2002: 44).

Negatywnym skutkiem gospodarki pieniężnej jest także zblazowanie, czyli zatracenie zdolności różnicowania wartości nabywanych przedmiotów. W tym przypadku następuje redukcja wszystkiego do bezkształtności, do zjawisk ilościowych (Simmel 1969), w których pieniądz stanowi w równej mierze ekwiwalent najbardziej różnorodnych przedmiotów, a różnice jakościowe sprowadza do różnic ilościowych, dzięki swemu neutralnemu charakterowi narzuca się jako wspólny mianownik wszystkich wartości. Pełni on funkcję niwelującą, nieodwołalnie pozbawiając przedmioty ich wewnętrznej treści, swoistości, wartości, nieporównywalnego charakteru. Wszystkie przedmioty są zatem - niezależnie od ich ciężaru gatunkowego - postrzegane z perspektywy nieprzerwanego nurtu pieniądza, wszystkie leżą na tej samej płaszczyźnie i różnią się tylko wielkością zajmowanej powierzchni (Simmel 2005: 309). W filozofii pieniądza proces reifikacji prowadzi do ucieleśnienia i symbolizowania umysłu w przedmiotach, a w konsekwencji do panowania nad ludźmi (Simmel 1997: 251-253). W skrajnym przypadku wartość człowieka redukuje się do wymiaru finansowego (Simmel 1997: 330).

Sprowadzanie najróżniejszych zjawisk do określonych kwot stwarza możliwość ich bezpośredniego porównywania. Jak zauważył Simmel, zasada pieniężna nie liczy się z wewnętrzną indywidualnością zjawisk. Pieniądz bowiem dotyczy tylko tego, co jest wspólne wszystkim przedmiotom, dotyczy wartości wymiennej, która sprowadza wszelką jakość i swoistość do pytania: ile? Wszelkie stosunki uczuciowe między ludźmi mają za podstawę cechy indywidualne, podczas gdy stosunki oparte na intelekcie posługują się ludźmi tak jak liczbami, jak elementami samymi w sobie bez znaczenia, interesującymi tylko ze względu na ich obiektywnie ocenianą skuteczność (Simmel 1969: 49). Powyższe uwarunkowania sprawiają, że wszelkie procesy i zjawiska stają się możliwe do zracjonalizowania i obiektywnej oceny, choć oczywiście istnieją sytuacje, których nie sposób w racjonalny sposób wytłumaczyć czy porównać. 
Pieniądz przyjmuje centralną rolę w życiu społecznym, stając się celem samym w sobie, zamiast być jedynie środkiem do osiągania różnych celów (Simmel 1997: 203). Stanowi przedmiot pożądania, którego nie sposób zastąpić. Prowadzi to w pierwszej kolejności do całkowitego zorientowania na gromadzenie jak największej ilości zasobów materialnych, a dopiero następnie do ewentualnej wymiany na określone dobra czy usługi, będące atrybutem przynależności do określonej grupy społecznej, kategorii społeczno-zawodowej itp. Gospodarka rynkowa stwarza zatem warunki do wyboru sposobów wydawania pieniędzy i samorealizacji, a także do większej swobody przemieszczania się i kreowania nowych rzeczy. Jest to możliwość swobody wyboru w zakresie stylu życia, który najbardziej odpowiada wyznawanym wartościom i odzwierciedla gusta (Simmel 1997). W takim ujęciu wielkość nagromadzonego kapitału ekonomicznego w postaci dostępnych środków finansowych, wysokiego poziomu zamożności należy traktować jako swoisty wyznacznik sposobu funkcjonowania w obrębie określonych grup społecznych, umożliwiający podążanie za aktualnie obowiązującymi trendami.

\section{Współczesny sposób funkcjonowania i zarządzania ryzykiem w kontekście postmodernizmu ekonomicznego}

Zmiana w sposobie funkcjonowania, o której pisał Simmel, i zwrot w kierunku wartości materialnych są przedmiotem rozważań także współczesnych teoretyków i badaczy kultury. David Harvey zwrócił uwagę na konsekwencje nadkumulacji kapitału w postaci specyficznego poczucia ścieśnienia czasu i przestrzeni. Wraz z postępującym rozwojem technologicznym wzrasta liczba zadań do realizacji oraz liczba sposobów ich realizacji i zmniejsza się ilość dostępnego czasu. Przestrzeń fizyczna we współczesnej rzeczywistości społeczno-gospodarczej została zastąpiona nową przestrzenią społeczną, zarządzaną przez nowe technologie wysoce zróżnicowanych i dynamicznych rynków (Harvey 2014: 151). Wyposażenie w nowoczesne gadżety, umożliwiające niemal nieograniczoną łączność i transfer danych, zdaje się generować wciąż coraz większą liczbę zadań do realizacji. Tym samym sytuacja ta nie pozwala nawet na chwilę zapomnieć o obowiązkach zawodowych. Rozwój nowoczesnych technologii, choć wydaje się pomocny w zwiększaniu efektywności realizowanych przedsięwzięć, jednocześnie stwarza zagrożenie całkowitego zatopienia się w pracy zawodowej. Pozornie umożliwia oszczędzanie czasu i środków finansowych, np. w przypadku połączenia telekonferencyjnego z bardzo odległym miejscem, jednak w rzeczywistości zaoszczędzony czas jest bardzo często wykorzystywany na wypełnianie kolejnych obowiązków zawodowych.

Nie ulega wątpliwości, że światowy system rynków zdominowany jest i powiązany z technologiami informacyjnymi. Rozwijająca się w takich uwarunkowaniach kultura wyłania się w dużej mierze z procesów ekonomicznych i wywiera wpływ nie tylko na ekonomię, lecz także na wszelkie inne aspekty życia społecznego (Harvey 2014: 177). Nowoczesne technologie stanowią już dzisiaj nieodłączny element codzienności, oddziałując na sposób funkcjonowania (Walsh 2011), przenikają niemal każdą sferę życia. Dostępność technologii, która w coraz większym stopniu zastępuje człowieka lub choćby wspiera realizację określonych zadań, jest powszechna, a nawet w niektórych przypadkach trudno sobie wyobrazić wykonanie jakiegoś zadania bez wykorzystania tego typu narzędzi. Zastanawiający jest proces postępu technologicznego w kontekście stawiania granic ludzkiej wyjątkowości i braku możliwości całkowitego wyeliminowania człowieka z procesu pracy.

W kapitalizmie wielonarodowym maszyny elektroniczne nie mają takiej samej zdolności wytwarzania znaczeń, ich przeznaczeniem bowiem jest w większym stopniu reprodukcja niż produkcja. Tym samym każdy znak jawi się w odosobnieniu lub w stosunkowo luźnym związku z pozostałymi znakami, przez co nie jest jednoznaczny, może być niemal dowolnie interpretowany. Ze względu na to, że proces reprodukcji jest zorientowany bardziej na medium niż na przekaz, dochodzi do schizofrenii kultury, czyli procesu polegającego na zerwaniu łańcucha znaczeniowego łączącego przedmiot ze znakiem. W związku z tym zmienia się rola języka, który traci zdolność do ugruntowywania pojęć czy też organizowania symboli w koherentne systemy pojęć. W niczym niepowiązanym systemie znaków znaczenie pojęć jest problematyczne, a indywidualne doświadczenia stają się seriami czystych, niepowiązanych uobecnień w czasie (Jameson 2009: 277-278). Komunikacja interpersonalna odbywa się coraz częściej z wykorzystaniem nowoczesnych technologii, co ma swoje konsekwencje właśnie w swobodnym interpretowaniu poszczególnych znaków i symboli. Do przekazu 
wkradają się często znaki graficzne, np. emotikony, a także wyrażenia ponadnarodowe, uniwersalne czy zapożyczone, które mogą zawierać bardzo dużą liczbę desygnatów i stwarzają możliwości swobodnej interpretacji.

W związku z powyższym istotnym problemem współczesności jest to - nad czym rozważał Fredric Jameson - w jaki sposób myśl może przewodzić działaniu i na odwrót, zwłaszcza że pojęcia, którymi się ona posługuje, są oderwane od warunków materialnych. Proces ten ulega przekształceniom i zdezawuowaniu, głównie za sprawą zmieniającego się charakteru znaczeń określonych pojęć, wyrażeń itp. Jest to efekt udziału tzw. maszyn symbolicznej reprodukcji, które niemal rozrywają bezpośrednie powiązania pomiędzy ludzką produkcją a jej symboliczną reprezentacją. W takich warunkach emocjonalnej płaskości, czy też braku głębi, zdolność jednostek do praxis znacznie zmalała (Jameson 2011). Przekazy skonstruowane na bazie wieloznacznych wyrażeń, zapożyczeń i słów uniwersalnych stają się coraz mniej efektywne. W procesie rekodowania pierwotny zamysł nadawcy co do treści zostaje bowiem zniekształcony. Dzieje się tak na skutek m.in. zbyt dużej liczby komunikatów płynących do odbiorcy z wielu stron jednocześnie i braku całkowitego skupienia na jednym, wybranym, w danej chwili najistotniejszym z nich, jak również błędów popełnianych podczas procesu kodowania treści przekazu przez nadawcę. Zniekształcenia i zakłócenia w komunikacji stanowią codzienność, w której prawdziwym zmaganiem wydaje się konstruowanie przekazów o wysokim poziomie abstrakcji. Oddziaływanie na bodźce emocjonalne człowieka, na jaźń i tożsamość wpisuje się bowiem we wszelkie formy komunikowania o charakterze komercyjnym, a więc niezwykle trudno zmobilizować odbiorcę do wytężonego wysiłku w postaci pogłębionej refleksji i zastanowienia się nad jakąś kwestią.

Wiele towarów i usług dystrybuowanych na współczesnych rynkach jest związanych właśnie z tworzeniem wyobrażeń na temat jaźni i tożsamości. Zatem rynek steruje wyobrażeniami kulturowymi poprzez kreowanie trendów czy promocję znaków firmowych, a także poprzez inne sposoby oddziaływania na kulturę. Dynamika kreowania nowych wizerunków kulturowych stanowi odpowiedź na nudę, przesyt i naśladownictwo, co prowadzi do przyspieszenia tempa produkcji i niestabilności produktów przeznaczonych do konsumpcji (Harvey 2014: 123-124). Nabywanie kolejnych przedmiotów o określonej marce, znaku firmowym często jest związane nie z samą ich użytecznością, ale raczej z symbolicznym znaczeniem (Baudrillard 2006). Stanowią one bowiem wyznacznik przynależności do określonej grupy społecznej, świadcząc o prestiżu, wysokim poziomie dochodów, znajomości aktualnych trendów itp. W obliczu kształtowania się nowych rynków prowadzi to do wyścigu, polegającego na nadążaniu za błyskawicznie zmieniającymi się trendami i pozbywaniu się rzeczy, uznanych za passé przez głównych graczy rynku.

Harvey i Scott Lash wskazali na powstanie nowej klasy sektora usług, zorientowanej na konsumpcję towarów, właśnie ze względu na ich siłę symboliczną. Oznacza to nabywanie dóbr wyłącznie w celu podkreślenia różnic w grupie, smaku, stylu życia, preferencji, orientacji płciowej, etniczności itp. W takim ujęciu elementem budowania tożsamości w coraz większym stopniu są symbole kulturowe oderwane od przestrzeni fizycznej (sąsiedztwo, region itp.) (Harvey 2014: 237). Znaczenie zyskują uznane w powszechnej opinii marki, znaki towarowe, które kształtują aktualne trendy na rynkach dóbr i usług. Otaczanie się przedmiotami prestiżowymi, drogimi, modnymi może świadczyć o wysokiej pozycji społecznej, zamożności, przynależności do elit, a więc być postrzegane jako wyznacznik sukcesu.

Współczesne style życia nie są już zrutynizowanymi praktykami, które odpowiadają nawykom żywieniowym, sposobom ubierania się, zachowania itp., ale, podlegając refleksyjności, stanowią codzienne wybory, których konsekwencją jest odpowiedź na pytanie, kim jestem lub kim chciałbym być. Są nieodzownie powiązane ze sferą konsumpcji, a także wyboru pracy zawodowej (Giddens 2007). Tym samym sposób funkcjonowania we współczesnej rzeczywistości społeczno-gospodarczej niesie za sobą szereg codziennych wyborów do dokonania, które nie tylko determinują efektywność realizacji poszczególnych zadań, lecz także mają znaczenie dla poczucia tożsamości. Nawet najdrobniejsze decyzje życia codziennego, według postmodernistycznej myśli społecznej, stanowią element tożsamościowy, a więc zdają się określać styl życia. Czy jednak pogoń za pożądanymi konsekwencjami decyzji nie prowadzi do zbytniego zorientowania na pewnych wyobrażeniach o własnej tożsamości? 


\section{W poszukiwaniu wyznaczników wzrostu kultury materialnej}

Analizę dotyczącą aktualności tezy o wzroście kultury materialnej oparto na danych zastanych uzupełnionych o badania własne (badania ilościowe w oparciu o próbę probabilistyczną). Z uwagi na sposób sformułowania postulatu Simmla jako pewnego uogólnienia konieczne było odniesienie się do analiz na poziomie makrostrukturalnym. Jak wskazywał bowiem Simmel (1906), własność prywatna nie jest oparta wyłącznie na własnych siłach jednostki, lecz wymaga warunków i sił środowiska społecznego. Wyjaśnienia zaobserwowanych przemian należy zatem poszukiwać w relacjach interpersonalnych, zarówno na poziomie mikro-, jak i makrostruktur. O ile w przypadku analizy procesów i zjawisk dotyczących mikrostruktur społecznych prawdopodobieństwo odnotowania pewnych subtelności w obrębie relacji do własności prywatnej wydaje się osiągalne, o tyle w przypadku makrostruktur nie jest to już takie oczywiste. Simmel zwraca jednak uwagę, że nagromadzenie tak wielkiej liczby ludzi i tak różnych interesów powoduje, że ich stosunki i zajęcia stapiają się, tworząc wieloczłonowy organizm (1969: 50). Wskazuje, że także w przypadku analizy procesów i zjawisk dotyczących makrostruktur możliwe jest zaobserwowanie analogicznych mechanizmów.

Za podstawowy materiał empiryczny uznano dane pierwotne - pozwalające z punktu poprawności metodologicznej na uogólnianie - uzyskane w projekcie badawczym Diagnoza spoteczna (Rada Monitoringu Społecznego 2018), które zostały wzbogacone o inne publikacje przytaczające wyniki badań opartych na reprezentatywnych próbach probabilistycznych. Badania własne, ze względu na ograniczony zasięg terytorialny, wykorzystano jedynie jako egzemplifikację wskazanych w niniejszej analizie ustaleń.

Centralna rola pieniądza w życiu społecznym dostrzeżona wiele lat temu przez Simmla również współcześnie wydaje się interesująca poznawczo. Jakkolwiek współczesne socjologiczne analizy z zakresu wpływu pieniądza na procesy i zjawiska w obrębie rzeczywistości społeczno-kulturowej najczęściej nie odnoszą się wprost do tego zagadnienia, nie oznacza to, że stanowi ono nietknięty obszar badań naukowych. W większości przypadków bowiem sposób oddziaływania pieniądza na relacje w obrębie struktury społecznej jest analizowany z perspektywy systemów aksjonormatywnych, a więc przez pryzmat badań kulturowych (Nobis 2014: 38).

Analiza kulturowa wskazuje m.in. na warstwę aksjologiczną struktury społecznej jako przedmiot szczególnie ważny dla socjologicznego spojrzenia. Zatem poszukując odpowiedzi na pytanie o wzrost kultury materialnej i centralną rolę pieniądza, warto przyjrzeć się uznawanym w ostatnich latach wartościom życiowym. Wśród najczęściej wskazanych przez Polaków wartości wyróżnia się m.in.: pieniądze (miejsce 5.), pracę zawodową (miejsce 7.), dobrobyt, bogactwo (miejsce 13.), życie pełne przygód i wrażeń (miejsce 15.) oraz sukces, sławę (miejsce 18.) (CBOS 2013; Bieńkuńska, Łysoń, Sobestjański 2015). Zarówno pieniądze, jak i praca zawodowa lokują się w pierwszej dziesiątce najczęściej uznawanych przez Polaków wartości życiowych. Z badań autora niniejszego tekstu wynika, że rozwój kariery zawodowej jest współcześnie istotnym bodźcem stymulującym i jedną z najważniejszych kwestii wymagających starań i zaangażowania. Praca zawodowa została wskazana na 8. miejscu w hierarchii wartości życiowych przez szczecińską młodzież akademicką (Klimek 2011). Ustalenie to nie powinno być zaskoczeniem, ponieważ współczesna rzeczywistość społeczno-gospodarcza ogniskuje się właśnie wokół życia zawodowego. Czas wolny jest pojęciem coraz trudniejszym do jednoznacznego określenia, zdefiniowania czy też zmierzenia za pomocą konkretnych jego mierników (Lipski 2008: 220-222).

Wartości materialne, zdefiniowane jako dobrobyt i bogactwo, wskazane zostały przez 5\% Polaków (CBOS 2013; Bieńkuńska, Łysoń, Sobestjański 2015). Z kolei w autorskich badaniach autora niniejszego tekstu wartości materialne wyrażone wprost jako pieniądze znalazły się na 5. miejscu ze wskazaniem 13,9\% respondentów (Klimek 2011). Wydaje się, że samo pojawienie się tego typu oczekiwań wyrażonych w formie uznawanych wartości życiowych może wskazywać na obecność wartości materialnych w systemie aksjonormatywnym społeczeństwa polskiego. Ponadto w zestawieniu z takimi wartościami życiowymi wskazanymi w badaniach, jak: życie pełne przygód i wrażeń oraz sukces, sława, można przypuszczać, że wzrost kultury materialnej, o którym pisał Simmel, pozostaje tendencją aktualną.

Warstwa aksjologiczna, choć zdaje się wyrażać obecność materialistycznego podejścia w życiu społeczno-kulturowym, nie dostarcza jednak wyjaśnienia przyczyn takiego sposobu życia. Rodzi się więc pytanie o to, co może być przyczyną centralnej roli pieniądza i wzrostu kultury materialnej? Jakie zjawiska i procesy społeczno-kulturowe zdają się determinować tę tendencję? 
W pierwszej kolejności należy przyjrzeć się efektom dynamicznie postępującej globalizacji, które odciskają piętno na współczesnej rzeczywistości. Rozwój technologii, w tym powszechna dostępność środków transportu, narzędzi komunikacji, aplikacji mobilnych itd., spowodował w ostatnich latach ogromne przemiany o charakterze społeczno-kulturowym. Przede wszystkim zmienił się charakter aktywności zawodowej, która przestała być postrzegana w kategoriach $m$.in. przestrzennych, a zaczęła w kategoriach instrumentalnych. Do tej pory bowiem praca zawodowa kojarzona była z określonym miejscem i sztywno wyznaczonymi ramami czasowymi, w trakcie których realizowano zlecone zadania. Obecnie w zdecydowanej większości przypadków przestrzeń nie ma aż tak dużego znaczenia, najważniejsze zaś jest realizowanie wielu zadań i celów jednocześnie w jak najkrótszym czasie. Wielozadaniowość, wysoki poziom mobilności, kreatywność i samodzielność stają się podstawowymi umiejętnościami w życiu zawodowym i nie tylko. Wobec tak niezwykle wysokiego poziomu dynamiki, nieustannej konieczności dostosowania się do zmieniającej się rzeczywistości, trudno jest nie dostrzec różnego rodzaju zagrożeń i ryzyka.

Ryzyko związane z utrzymaniem zdrowia (fizycznego i psychicznego) staje się nieodłącznym elementem życia jednostki. Biorąc pod uwagę, że zachowanie człowieka często uwarunkowane jest doświadczeniem zapośredniczonym, w powiązaniu z jego zdolnością do racjonalizowania i kalkulowania, uleganie lękowi związanemu z ryzykiem zwykłego funkcjonowania powinno być z zasady powszechne. Jeśli tak się nie dzieje, to dzięki podstawowemu zaufaniu, rozumianemu jako przekonanie o własnym bezpieczeństwie (Giddens 2007: 57).

Anthony Giddens zwraca także uwagę na kreatywność jako czynnik zdeterminowany przez rutynę i ściśle związany z podstawowym zaufaniem. Element kreatywności jest naturalną częścią składową zaufania, warunkuje on bowiem przeskok w nieznane, zgodę na ryzyko, równoznaczne z gotowością do przyjęcia nowych doświadczeń, w tym także możliwości straty. Każda ewentualność poniesienia straty skłania do wysiłku (Giddens 2007: 58). Wyznacznikiem kreatywności jest przekonanie o własnym wpływie na rzeczywistość. Taka postawa wydaje się utrwalana współcześnie i wiąże się z poszukiwaniem sposobów minimalizowania ryzyka, np. poprzez gromadzenie kapitału ekonomicznego, który w razie potrzeby pomoże rozwiązać napotkany problem.

Jak wynika z danych Diagnozy spotecznej (Rada Monitoringu Społecznego 2018), zdecydowana większość Polaków (81,2\%) uważa, że każdy jest kowalem swojego losu. Przeciwnego zdania jest jedynie 6,5\% osób biorących udział w badaniu. Funkcjonowanie w rzeczywistości gospodarki globalnej i konkurowanie na rynku pracy wiąże się z silnym przekonaniem o wyłącznie osobistej odpowiedzialności za własny los. Respondenci zdają się głosić, że nikt nie będzie interweniował, jeżeli jednostka samodzielnie nie zatroszczy się o rozwój osobisty (w wymiarze edukacyjnym, zawodowym, osobowościowym, rodzinnym, towarzyskim itp.).

Gwałtownie przebiegające procesy globalizacyjne skutkują wyłonieniem ryzyka na wielką skalę, którego czynniki mają szczególny charakter. Spotykane współcześnie zagrożenia będą towarzyszyły zmianom społecznym i technicznym w postaci trudnych do przewidzenia skutków. Nie sposób jednak precyzyjnie oszacować ryzyka ludzkiego błędu lub sabotażu (Giddens 2002: 168-170). Wobec takich uwarunkowań coraz trudniej planować przyszłość, wyznaczać odległe cele, ponieważ jest to nieuchronnie związane z ryzykiem. Zatem rzeczywistość sprowadzona zostaje do codzienności, do „tu i teraz”. Liczy się to, co jest dostępne w danej chwili, bez konieczności długiego wyczekiwania. W konsekwencji spełnienie określonych pragnień nie pozwala na pełne zaspokojenie oczekiwań, a jedynie na tymczasową satysfakcję, po której przychodzi kolejne pożądanie. Dostęp do zasobów materialnych (kapitału ekonomicznego) z pewnością daje większe możliwości realizacji coraz bardziej wysublimowanych zachcianek.

Jednym z wyznaczników stylu życia ukierunkowanego na wartości materialne może być postawa wobec posiadania przez inne osoby dóbr luksusowych. Sposób postrzegania osób posiadających przedmioty, na które nie każdy może sobie pozwolić, może bowiem świadczyć o pewnych pragnieniach czy też dążeniach (celach o charakterze materialnym). Jak wynika z Diagnozy spotecznej (Rada Monitoringu Społecznego 2018), niemal co trzeci Polak (30,8\%) podziwia ludzi, którzy mają drogie domy, samochody i ubrania, co może świadczyć o wyraźnej obecności kultury materialnej. Z kolei niemal połowa społeczeństwa polskiego $(48,2 \%)$ nie wyraża podziwu dla posiadania dóbr luksusowych. 
Opisywane przemiany, wynikające z rozwoju społecznego czy też rozwoju nowoczesnych technologii, w tym narzędzi i aplikacji komunikacyjnych, prowadzą do instrumentalizacji relacji interpersonalnych. Wszelkie interakcje coraz częściej są podejmowane ze względu na konieczność realizacji partykularnych interesów, zleconych zadań czy chęci osiągnięcia określonych celów. Kształtowanie głębszych relacji wydaje się dzisiaj zamierzeniem utopijnym, które wymaga poświęcenia zbyt dużej ilości - tak przecież cennego czasu. Wartościująca ocena innych osób może być zatem trafnym wyznacznikiem zjawiska opisanego przez Baumana terminem „zindywidualizowane społeczeństwo” (2008). Innymi słowy, ocena wartościująca może wskazywać na instrumentalny charakter relacji interpersonalnych.

Dane z Diagnozy społecznej (2018) wskazują, że niemal połowa Polaków (46,0\%) zgadza się ze sformułowaniem, że niektórzy ludzie są więcej warci od innych. Przeciwnego zdania jest co trzecia osoba, która brała udział w badaniu (34,3\%). Skłonność do oceny niektórych osób w sposób lepszy od innych może świadczyć o instrumentalnym traktowaniu relacji interpersonalnych, przy czym nie chodzi tutaj o sytuację, w której należałoby pozbawiać się prawa do oceny w ogóle, ale o rzeczywiste dzielenie ludzi na lepszych (więcej wartych) i gorszych (mniej wartych). Nie wchodząc w dyskurs, którego przedmiotem jest ocena jednostki ze względu na aspekty moralne, wydaje się niestosowne, aby w jakichkolwiek warunkach dokonywać całościowej oceny osoby zamiast jej konkretnych postaw, zachowań itp.

Realizacja coraz bardziej wyszukanych pragnień, hedonistyczny styl życia, instrumentalizacja relacji interpersonalnych itp. wyznaczają kierunek podążania za kolejnymi „atrakcjami” codzienności. Nie sprzyja to kreowaniu poczucia własnej wartości i tożsamości. Coraz trudniej jest udzielić odpowiedzi na pytanie, kim jestem lub kim chciałbym być. Problemem jest coraz częściej odnalezienie własnej drogi i nieuleganie wpływom globalnych trendów (Kubera 2013).

Dynamika przemian współczesnej rzeczywistości globalnej charakteryzuje się bowiem dążeniem do uniformizacji czy też standaryzacji. Jest to sposób minimalizowania ryzyka i pewna próba radzenia sobie z potencjalnymi zagrożeniami. Standaryzacja nie oznacza braku różnorodności, ale sprowadza się do utrwalenia określonych schematów, w ramach których możliwe są jedynie pewne modyfikacje. W przypadku zachowań konsumpcyjnych chodzi o wytworzenie pewnych potrzeb wśród klientów, określenie standardu, poniżej którego „nie wypada zejść”. Tym samym tworzy się rynek, którego wcale nie należałoby postrzegać jako szeroki, lecz właśnie jako podlegający trendom wytworzonym przez dużych „graczy”. Kreowany jest określony styl życia, z nieodzownymi akcesoriami o charakterze materialnym, np. gadżetami, bądź też niematerialnym, np. zdrowy tryb życia.

Współczesne trendy wskazują m.in. właśnie na zdrowie jako główny element refleksyjnego projektu ,ja”. Instytucjonalna refleksyjność nowoczesności koncentruje się bowiem na kreacji ciała. Zatem planowanie, jak również wybór jakiegoś stylu życia wiążą się z poddawaniem ciała określonym reżimom (Giddens 2007: 137-142). Warto dodać, że zachowanie dobrego zdrowia (89,1\%) stanowi wartość wskazywaną przez największy odsetek Polaków (CBOS 2013; Bieńkuńska, Łysoń, Sobestjański 2015).

Uleganie aktualnym trendom globalnych rynków uwidacznia się także w zjawisku konsumpcjonizmu. Jak bowiem wskazują badacze rynków, Polaków cechuje fascynacja konsumpcją i skłonność do bycia spontanicznymi nabywcami. Oznacza to kupowanie dóbr pod wpływem chwili, pomimo że nie zawsze są one potrzebne. Co istotne, eksperci podkreślają, że postawy te wynikają właśnie z wpływu aktualnych trendów, konsumpcji demonstracyjnej, orientacji na „tu i teraz” (Dąbrowska 2015: 98), co zdają się także potwierdzać dane z Diagnozy społecznej (Rada Monitoringu Społecznego 2018). Wynika z nich, że co trzecia osoba zamieszkująca w Polsce $(33,7 \%)$ wyraża przekonanie, że posiadanie dóbr materialnych to miara życiowego sukcesu. Przeciwnego zdania jest niemal połowa Polaków (44,2\%). W tym przypadku konsumpcjonizm jest sposobem funkcjonowania w określonych grupach społecznych, zorientowanym nie tyle na posiadaniu przedmiotów dla funkcji użytkowych czy estetycznych, ile posiadaniu dla samego posiadania, tj. podkreślenia przynależności do określonej grupy (Baudrillard 2006).

Analizując zjawisko konsumpcjonizmu, należy jednak zauważyć, że zachwyt nad możliwościami dostępu do dóbr przerodził się w inny wymiar ich nabywania, co oznacza, że utowarowienie ma dziś niewątpliwie granice, istnieją bowiem konkurencyjne wobec rynku i wygrywające z nim formy regulacji życia społecznego. Nie można jednak wykluczyć, że galopująca komercjalizacja owe granice przesunie (Iwasiński 2015: 21). Jednym 
z przykładów ewolucji w obrębie konsumpcjonizmu jest jej upodmiotawiający charakter. Powszechność interaktywności pozwala na opartą na dialogu komunikację klienta z producentem. W efekcie możliwe jest zindywidualizowane wytwarzanie, na potrzeby coraz mniejszych segmentów, niekiedy wręcz indywidualnych konsumentów. Mamy więc do czynienia z większą personalizacją dóbr i usług, a nierzadko z możliwością ich współtworzenia w efekcie rozwoju prosumpcji (Iwasiński 2016: 106).

\section{Wnioski}

W oparciu o powyższą analizę wydaje się, że głoszona przed wielu laty teza Simmla dotycząca wzrostu kultury materialnej pozostaje wciąż aktualna, chociaż z pewnością wymaga dalszej, pogłębionej, systematycznej weryfikacji. Nie zapominając bowiem o dynamice życia społeczno-gospodarczego, nie można pozostać przy jednoznacznych twierdzeniach czy przekonaniach o rzeczywistości, nawet jeżeli wszelkie przesłanki zdają się wskazywać na określoną tendencję.

Przejawem opóźnionej odpowiedzi kulturowej w stosunku do nowych wzorów przemieszczania kapitału w czasie i przestrzeni jest m.in. blokada zmysłów, wzrastająca tęsknota za przeszłością czy też nasilająca się pogoń za uniwersalnymi prawdami i wartościami oraz tożsamością kolektywną lub osobistą (Harvey 2014: 273). Odpowiedzią na współczesne trendy konsumpcjonizmu i uznania wartości materialnych wydaje się skrajne radykalizowanie postaw, np. wyrażone poprzez pochwałę sposobu funkcjonowania w dawnych czasach, które wiąże się z zapewnieniem bezpieczeństwa ontologicznego jednostki. Ponadto uznanie i poszukiwanie w codzienności uniwersalnych prawd i wartości jest także dążeniem do minimalizowania ryzyka związanego z zagrożeniami wyzwań codzienności i jej niepewnością. Podobnie jest z potrzebą określenia własnej tożsamości lub chociażby tożsamości kolektywnej, które pozwala na normalne funkcjonowanie, pozbawione niepokoju i obaw o brak jakiegokolwiek przyporządkowania. Bycie nieokreślonym oznacza w dzisiejszym świecie izolację społeczną i może prowadzić do całkowitego wykluczenia społecznego.

Zarządzanie ryzykiem związanym z niedostatkami w obszarze afirmacji, przynależności do określonej grupy społecznej czy kategorii społeczno-zawodowej, prestiżu, pozycji społecznej itd. jest procesem tożsamościowym, związanym z codzienną koniecznością dokonywania wyborów. Każda, nawet najmniejsza decyzja wpływa na projekt ,ja”, co w przypadku chęci projektowania własnej tożsamości, dążenia do określonej wizji przyszłości powinno uruchamiać wysoki poziom refleksyjności, a niekiedy także racjonalności i chłodnej kalkulacji. Pozostaje postawić w tym miejscu pytanie przede wszystkim o to, czy realizacja takiego scenariusza jest możliwa i czy nie prowadzi do całkowitego zinstrumentalizowania relacji interpersonalnych. Zapewne przy jasno zdefiniowanych celach i priorytetach oraz dużym poziomie dyscypliny i konsekwencji osiągnięcie upragnionego „statusu szczęśliwości” wydaje się realne, ale czy oznacza rzeczywiście to, co zostało pierwotnie zaprojektowane, czy pozostaje tylko utopijnym projektem? Być może jest to jedynie status oparty na fałszu własnych marzeń, pragnień, ambicji, aspiracji, tj. osiągnięty poprzez relacje interpersonalne oparte na zakłamaniu, wymuszeniu, handlu itp.

Wydaje się, że kwestią kluczową dla współczesnych relacji interpersonalnych jest zaufanie. Posługując się językiem Piotra Sztompki należy podkreślić, że niepewne zachowania innych ludzi zmuszają do dokonywania codziennych zakładów przynajmniej w obrębie zaufania osobistego czy pozycyjnego, ale także komercyjnego i technologicznego (2007). Oznacza to, że należy wciąż przyjmować postawę otwartości i ufności, do której zachęcał wiele lat temu Simmel, wskazując, że zaufanie człowieka do człowieka posiada przecież wysoką wartość moralną: może nawet wyższą niż pozostałe wartości, gdyż jest aktem swobodnym i z tego powodu bardziej zasługuje na uznanie (Simmel 2005: 258-259).

\section{Bibliografia}

Baudrillard J. (2006), Spoteczeństwo konsumpcyjne. Jego mity i struktury (tłum. S. Królak). Warszawa: Wydawnictwo Sic!.

Bauman Z. (2006), Praca, konsumpcjonizm i nowi ubodzy (tłum. S. Obirek). Kraków: Wydawnictwo WAM. 
Bauman Z. (2008), Zindywidualizowane spoteczeństwo (tłum. O. i W. Kubińscy). Gdańsk: Gdańskie Wydawnictwo Psychologiczne.

Bourdieu P. (2005), Dystynkcja. Spoteczna krytyka wtadzy sadzenia (tłum. P. Biłos). Warszawa: Scholar.

Bieńkuńska A., Łysoń P., Sobestjański K. (2015), Prezentacja pierwszych wyników II edycji badania spójności spotecznej. Warszawa: Główny Urząd Statystyczny.

CBOS (2013), Wartości i normy. Komunikat z badań. Warszawa: Centrum Badania Opinii Społecznej.

Dąbrowska A. (2015), Postawy polskich konsumentów - od konsumpcjonizmu do zrównoważonej konsumpcji. „Handel Wewnętrzny” 2(355), s. 88-100.

Giddens A. (2007), Nowoczesność i tożsamość. Ja i spoteczeństwo w epoce późnej nowoczesności (tłum. A. Szulżycka). Warszawa: Wydawnictwo Naukowe PWN.

Harvey D. (2014), Seventeen Contradictions and the End of Capitalism. New York: Oxford University Press. Iwasiński Ł. (2015), Spoteczeństwo konsumpcyjne w ujęciu Zygmunta Baumana. „Kultura i Społeczeństwo” 4, s. 3-22.

Iwasiński Ł. (2016), Próba systematyzacji pojęcia konsumpcjonizmu. „Społeczeństwo i Polityka” 1(46), s. 93-107.

Jameson F. (2011), Postmodernizm, czyli logika kulturowa późnego kapitalizmu (tłum. M. Płaza). Kraków: Wydawnictwo Uniwersytetu Jagiellońskiego.

Jameson F. (2009), Valences of the Dialectic. New York: Verso.

Klimek J. (2011), W kierunku wartości postmaterialistycznych. Komunikat z badań nad systemami aksjo-normatywnymi mtodzieży akademickiej w epoce późnej nowoczesności. „Edukacja Humanistyczna” 2(25), s. 115-121.

Kubera J. (2013), Po postmodernizmie, czyli silne identyfikacje i stabe tożsamości. „Nauka” 1: 97-108.

Lipski A. (2008), Czas wolny w czasie życia. Przyczynek do analizy spoteczeństwa nowoczesnego. „Ruch Prawniczy, Ekonomiczny i Socjologiczny" 4, s. 205-223.

Nobis A. (2014), Globalizacja jako postęp i kryzys. „Kultura i Wartości” 2(10), s. 35-44.

Rada Monitoringu Społecznego (2018), Diagnoza społeczna: zintegrowana baza danych, www.diagnoza. com [dostęp: 21.09.2018].

Sikorski C. (2002), Dysonanse kulturowe w organizacji. „Zarządzanie Zasobami Ludzkimi” 3-4, s. 35-46.

Simmel G. (1906), The Sociology of Secrecy and of Secret Societies. „The American Journal of Sociology” 11(4), s. 441-498.

Simmel G. (1957), Fashion. "The American Journal of Sociology" 62(6), s. 541-558.

Simmel G. (1969), The Metropolis and the Mental Life [w:] R. Sennet (ed.), Classic Essays on the Culture of Cities. New Jersey: Prentice-Hall Inc., Englewood Cliffs, s. 47-60.

Simmel G. (1997), Filozofia pieniądza (tłum. A. Przyłębski). Poznań: Wydawnictwo Fundacji Humaniora.

Simmel G. (2005), Socjologia (tłum. M. Łukasiewicz). Warszawa: Wydawnictwo Naukowe PWN.

Simmel G. (2007), Filozofia kultury. Wybór esejów (tłum. W. Kunicki). Kraków: Wydawnictwo Uniwersytetu Jagiellońskiego.

Sztompka P. (2007), Zaufanie. Fundament spoteczeństwa. Kraków: Znak.

Walsh R. (2011), Lifestyle and Mental Health. „American Psychologist” 66(7), s. 579-592.

Włodarczyk K. (2015), Jakość życia postrzegana przez Polaków w XXI wieku. „Konsumpcja i Rozwój” 1(10), s. 3-16. 